\title{
ANALISIS SEMIOTIKA ROLAND BARTHES TENTANG FENOMENA JILBOOBS
}

\author{
Hamidah / Ahmad Syadzali
}

\author{
Fakultas Ushuluddin dan Humaniora \\ IAIN Antasari Banjarmasin
}

Diterima tanggal 3 Oktober 2016 / Disetujui tanggal 20 Oktober 2016

\begin{abstract}
Hijab/jilbab is a cloth to cover all of women's body except face and two palms. Now, there is one controversial Hijab trend, which is Jilboobs phenomenon. Basically, jilboobs means have deviation meaning from the nature of veil. Jilboobs is a critic to Muslim women who wear hijab, but they still wear tight dress or blouse. It causes their indentation body looked very clear, especially in her chest. Then, the jilboobs phenomenon is a sign in fashion culture which very interference how Muslim teenagers to dress up now. The function of jibab is not to cover women genitals anymore, but it becomes a mode that break out the religion rules. The jilboobs phenomenon is a negative connotation from the real jilbab function. The writers used Semiotics theory from Roland Barthes to discuss this jilboobs phenomenon. It tried to reveal about abusing the real jilbab function as covering Muslim women's genitals and a religion symbol.
\end{abstract}

Kata kunci: Agama, Hijab/Jilbab/Kerudung, Jilboobs, Fashion dan Tanda

\section{Pendahuluan}

Agama Islam adalah Agama yang tidak membatasi dalam keindahan, baik secara lahiriah maupun bathiniah, karena Ia merupakan sistem yang datang dari Tuhan. ${ }^{1}$ Dalam Islam sendiri juga memandang bahwa perempuan merupakan sesuatu yang indah. Oleh karena itu ajaran islam menghargai keindahan tersebut dengan cara menjaganya dengan batasan-batasan, agar perempuan terjaga dari berbagai hal yang tidak diinginkan, baik secara dzahir maupun batin. ${ }^{2}$ Salah satu cara Islam menjaga perempuan adalah dengan mewajibkannya untuk menutup aurat(tubuh yang haram untuk ditampakkan) dari ujung rambut sampai ujung kakinya, kecuali wajah dan telapak tangan. Dengan cara berpakaian yang sopan, tidak ketat dan tidak transparan serta memakai hijab (penutup kepala). ${ }^{3}$

Kata Hijab disini biasa disebutkan untuk kain yang biasa digunakan untuk menutup aurat perempuan. Berdasarkan ayat "Katakanlah kepada wanita yang beriman. Hendaklah mereka menahan pandangan mereka, dan memelihara kemaluan mereka, dan jangan lah mereka menampakekan perbiasan mereka (biasa) tampak dari mereka. Dan bendaklah mereka menutupkan kain kudung ke dada mereka. (QS Al-Nur: 31).

Kemudian ada beberapa syarat berpakaian ketika menggunakan hijab yaitu : menutupi seluruh tubuh kecuali yang boleh ditampakkan, tidak berupa perhiasan yang mewah, tidak tipis, tidak ketat, tidak memakai parfum yang bisa menarik perhatian banyak orang, tidak menyerupai pakaian laki-laki dan tidak menyerupai pakaian orang-orang kafir(seperti gaya fashion barat dan lain-lain) dan tidak berupa pakaian bermerk terkenal(seperti Sophie Paris, IFA dan lain-lain), karena bisa menyebabkan kesombongan.

Tak lepas dari penjelasan diatas, ada salah satu masalah yang dihadapi oleh kaum perempuan muslim di era saat ini. Berbagai variasi gaya berhijab yang menuntut kekreatifitasan para Hijabers. Khususnya para remaja yang sering mengikuti tren Fashion yang menyalahi dalam ajaran Islam. Tidak sedikit remaja Islam yang berhijab tetapi seakan tidak berhijab, dengan kata lain seperti yang ada pada zaman sekarang yaitu tren Jilboobs. Dengan kata lain Jilboobs adalah gaya berhijab perempuan yang ketat sehingga memperlihatkan bentuk payudara yang tidak seharusnya terekspos. Dari hal ini fenomena Jilboobs menjadi perbincangan yang cukup kontroversial. Komunitas Jilboobs awal nya dikenal hanya di dunia maya seperti Facebook, tetapi sekarang

${ }^{1}$ Fuad Farid Ismail \& Abd. Hamid Mutawalli, Cara Mudah Belajar Filsafat Barat dan Islam (Jogjakarta: IRCISoD, 2012$), 28$.

2Ibrahim Muhammad Al-Jamal, Tantangan Wanita Muslimah (Jakarta: Pustaka Azzam, 2000), 29.

${ }^{3}$ M. Quraish Shihab, M. Quraish Shibab Menjawab (Tangerang: lentera hati, 2012), 761. 
malah menjadi salah satu tren Fashion dikalangan remaja. Dan fenomena Jilboobs ini adalah suatu tanda yang merupakan konotasi negatif dari fungsi Jilbab. Karena arti Jilboobs sendiri telah mengalami pergeseran dari makna jilbab yang sesungguhnya.

\section{Wacana tentang Jilbab}

1. Etimologi Jilbab

Jilbab dalam bahasa Inggris "Veil" dipakai sebagai penutup kepala yang tradisional, wajah (mata, hidung atau mulut), atau tubuh wanita di Timur tengah dan Asia selatan. Kata Veil dalam perspektif religius bermakna pengasingan diri dari kehidupan dunia dan kebutuhan seksual, sebagaimana kehidupan atau sumpah para biarawati. Definisi Kristen terhadap istilah barat Veil ini tidak dikenal secara umum. Justru persepsi yang lebih dikenal adalah bahwa $V$ eil itu lebih diasosiasikan pada wanita Arab dan Islam. ${ }^{4}$

Beberapa istilah yang dapat disebutkan disini angtara lain burqu', 'abayah, tarbah, burnus, jellabah, bayik, milayah, gallabiyah, disdasya, gargush, gina, munguh, yashmik litsmah, habarah, izar beberapa di antaranya merujuk pada penutup muka saja, yaitu burqu', gina' niqab. Sedangkan yang lain merujuk kepada penutup kepala yang kadang-kadang digunakan pula untuk menutup sebagian muka, seperti khima, abayah atan imamah. Sebagai tambahan, beberapa dari istilah ini yang merujuk pada pakaian yang dikenakan secara identik atau dalam bentuk yang sama baik itu laki-laki maupun perempuan, dengan peristilahan yang sama pula. Beberapa yang lain mengandung identitas gender rangkap. Sementara yang lain bersifat netral. Sebagai contoh, perempuan maupun laki-laki memakai pakaian luar seperti mantel dan penutup muka. Misalnya, Litsmah merupakan istilah yang dipakai penutup muka bergender rangkap, yang di Yaman dipakai oleh wanita dan diasosiasikan pada kewanitaan, namun pada sebagian masyarakat Badui dan Barbar dipakai oleh laki-laki serta diasosisikan pada kejantanan dan kelelakian. Beberapa contoh lain yang netral gender misalnya 'abayah di Arab dan burnus diwilayah Maghribi.

2. Jilbab dalam Kajian Wanita

Di Barat, kata veil digunakan untuk apa saja, baik sebagai judul buku, artikel, tema konferensi, media massa maupun film-film dan literatur. Beberapa sarjana pengkaji islam telah menunjukkan perhatian bahwa "jilbab" telah menggantikan "Bulan Sabit" sebagai simbol Islam di Barat, yang mana ini cukup menyakitkan. Agaknya, Jilbab telah datang untuk menggantikan obsesi sebelumnya yang terkandung dalam Harem dan Hummam kemudian jilbab saat ini membangkitkan energi seksual pulik yang sebelumnya tidak pernah sanggup dimunculkan, dipahami atau ditoleransi oleh Kristen awal dan elemenelemen fundamentalis Kristen sekalipun. Dibarat, kata-kata "Harem, Veil dan Poligami" mengandung citra yang menyudutkan Islam serta dengan Sinonim yang menunjukkan kelemahan dan penindasan wanita. ${ }^{5}$

3. Sejarah dan Perkembangan Jilbab

Kerudung/Hijab/Jilbab awalnya adalah sebuah benda yang kemunculanya akibat dari dorongan syariat, artinya munculnya ide budaya materi Kerudung/Hijab/Jilbab adalah berasal dari hukum Allah yang jelas, sudah diberi definisi dan ketentuan apa yang dimaksud, dan dalam kadar seperti apa sesuatu bisa disebut sebagai sebuah Kerudung/Hijab/Jilbab (Al-Qur'an surat An - Nur (24): 31). Sehingga manusia tinggal memahami kemudian mewujudkanya. Dalam konteks ini, penulis menafsirkan awalnya Kerudung/Hijab/Jilbab masih sebatas sebagai fungsi teknis, artinya baru sebatas sebagai sebuah benda yang memiliki fungsi untuk menutupi bagian tubuh yang dilarang untuk dilihat oleh orang lain, untuk menghindari maksiat bagi yang melihat (Al-Qur'an surat Al-Ahzab (33): 59). Kemudian fungsi Kerudung/Hijab/Jilbab tidak hanya sebatas sebagai fungsi teknis saja. Karena dalil tidak sebatas itu dalam memerintah, akan tetapi Kerudung/Hijab/Jilbab juga sebagai sebuah identitas bagi si pemakainya. akibatnya masyarakat Arab yang memakai Kerudung/Hijab/Jilbab sesuai syariat memiliki identitas sosial baru, yaitu sebagai seorang wanita muslim yang dihormati dan lelaki segan dan tidak menggangu, demikianlah catatan sejarah berkata. Sehingga jika Kerudung/Hijab/Jilbab dikaitkan sebagai sebuah identitas sosial kaitanya dengan keagamaan, maka pembacaan Kerudung/Hijab/Jilbab berkembang lagi, tidak hanya sebatas teknofak, dan sosiofak akan tetapi fungsi ideofak otomatis juga melekat karena Kerudung/Hijab/Jilbab adalah bagian dari syariat agama islam, yang tak lain Islam sebagai sebuah ideologi bagi sebagaian manusia dimuka bumi ini. ${ }^{6}$

${ }^{4}$ Fadwa El Guindi, JILBAB Antara Kesalahan, Kesopanan dan Perlawanan (Jakarta: Serambi Ilmu Semesta, 2005), 29.

${ }^{5}$ Fadwa El Guindi, JILBAB Antara Kesalahan, Kesopanan dan Perlawanan, 29.

${ }^{6} \mathrm{Fadwa}$ El Guindi, JILBAB Antara Kesalahan, Kesopanan dan Perlawanan, 30. 
Abad ke 7 adalah abad di mana awal perintah berkerudung/berhijab, dalam konteks abad ke 7 di semenanjung Arabia, kondisi sosial masyarakat jauh dari pengaruh peradaban dua imperium besar yaitu Romawi dan Persia. Hal ini sebagai dampak dari geomorfologi Arab yang terpencil dan terkukung dari pegunungan dan padang pasir, hal ini berdampak pada pengaruh budaya yang cukup kecil terjadi, sehingga apa yang dikembangkan oleh masyarakat masih sesuai dengan doktrin yang ada di lingkungan masyarakat Arab. Kerudung/Hijab/Jilbab sebagai sebuah hasil pemahaman atas dalil agama juga belum mengalami perubahan akibat pengaruh dua pusat kebudayaan dan masih sesuai dengan makna, dan ketentuanya, yang dimaksud disini sesuai dengan dalil adalah Kerudung/Hijab/Jilbab berarti: kain penutup kepala sehingga kain menjulur hingga dada. Hal ini dapat ditarik sebuah pengetian bahwa masyarakat pendukung kebudayaan Kerudung/Hijab/Jilbab pada awalnya masih memegang teguh ketentuan-ketentuan dalil tentang Kerudung/Hijab/Jilbab, dan belum terfikirkan untuk merubah makna Kerudung/Hijab/Jilbab. ${ }^{7}$

Pasca Islam pada abad ke 9-12 mengalami perkembangan dan persebaran mengalami akulturasi dengan kebudayaan lainya, misalnya di sebagian Negara Timur-Tengah berkembang model Kerudung/Hijab/Jilbab dengan cadar, burqa, niqab, dan masker, kemudian berkembang pula di Nusantara atau Melayu abad 19 Kerudung/Hijab/Jilbab selendang yang tidak menutupi penuh kepala, dan hanya di selampirkan. di kawasan timur juga berkembang Kerudung/Hijab/Jilbab dengan motif hiasan tertentu sesuai dengan konteks lingkunganya, tidak sebatas polos tanpa motif, dan lain sebagainya. Hal ini menggambarkan bahwa ada sebuah perkembangan dalam berupaya untuk menafsiakan Kerudung/Hijab/Jilbab. Faktornya tentu banyak, hal ini terkait dengan kondisi sosial budaya, lingkungan, dan pemahaman atas dalil agama.

Singkatnya dalam konteks kondisi sosial-budaya misalnya: pendapat yang masih menjadi perdebatan para ahli, bahwa khususnya di Jawa pada abad 19, masih sedikit masyarakat yang memakai Kerudung/Hijab/Jilbab sesuai ketentuan dalil, hanya sebatas selendang yang diselampirkan di kepala, hal ini sebagaian berpendapat bahwa, hal ini sebagai dampak pola penyebaran agama islam yang dilakukan oleh Wali Songo, yang sangat toleran dengan budaya lokal, sehingga pada waktu itu Wali Songo baru menyampaikan masalah Teologis belum sampai pada masalah fiqih Kerudung/Hijab/Jilbab, karena menyadari bahwa hal ini akan merubah budaya berpakaian masyarakat jawa yang sangat mencolok. Contoh lain dalam konteks kondisi lingkungan alam: misalnya pada masyarakat di Melayu, yang memakai Kerudung/Hijab/Jilbab dengan bahan dan motif yang lebih variatif, hal ini menggambarkan kondisi bahan baku Kerudung/Hijab/Jilbab, yang sesuai dengan kondisi sumber daya alam masyarakat pendukungnya. Dan contoh yang terakhir adalah perubahan Kerudung/Hijab/Jilbab karena pemahaman dalil agama yang menyebabkan berubahanya Kerudung/Hijab/Jilbab. Misalnya saja Cadar yang masih menjadi perdebatan para ulama dalam hal keharusanya memakai. ${ }^{8}$

\section{Perubahan Tutorial Kerudung/Hijab/Jilbab Kreatif}

Yang dimaksud Kerudung/Hijab/Jilbab Kreatif dalam hal ini adalah sebuah Kerudung/Hijab/Jilbab yang penulis anggap hilang dari sisi nilai-nilai ideologis sebagai dasar kemunculnya, dan bergeser yang lebih menonjol pada sisi gaya hidup atau sebuah mode. Kemudian munculnya Kerudung/Hijab/Jilbab kreatif juga menumbuhkan sebuah klasifikasi yang baru, hal ini sebuah fenomena yang biasa dalam konteks zaman sekarang. Misalnya kita berangkat dari sebuah contoh, agar mudah menggambarkan hal ini. Ragam atau model pada budaya materi celana Jeans (sebagai simbol popular di Amerika). ${ }^{9}$ Misalnya, tahun 70 -an umum telah berkembang model calana jeans Cutbrai, baru pada tahun 90-an model ini sempat menghilang, dan kembali muncul tahun 2007. Kemudian model ini tahun 2010 menghilang karena model celana Jeans pensil. Gaya celana pensil ini secara otomatis akan menganeliasi gaya Cutbraiy, sehingga jika ada remaja yang masih memakai celana Jeans cutbraiy saat ini dalam perspektif klasifikasi Fashion dia akan masuk pada golongan mode kuno. Hal ini terjadi secara otomatis, sehingga celana pensil dalam waktu sekejap menjamur dan dipakai segala lapisan masyarakat yang selalu tidak mau ketinggalan mode.

Nampaknya begitu juga dengan Kerudung/Hijab/Jilbab ini. Kerudung/Hijab/Jilbab ini mulai menjamur, apalagi dengan dukungan media massa dan elektronik, Kerudung/Hijab/Jilbab ini siap-siap akan menjadi pusat perhatian baru, sehingga masyarakat akan banyak memburu model ini. Dalam perkembangan

${ }^{7}$ Fadwa El Guindi, JILBAB Antara Kesalahan, Kesopanan dan Perlawanan, 30-31.

${ }^{8}$ Fadwa El Guindi, JILBAB Antara Kesalahan, Kesopanan dan Perlawanan, 32.

${ }^{9}$ Akbar S. Ahmed, Posmodernisme (Budaya dan Harapan bagi Islam) (Bandung: Mizan, 1993), 200. 
waktu seperti yang berlaku pada celana jeans, bahwa jika masih ada yang menggunakan Kerudung/Hijab/Jilbab "formal" maka secara otomatis dia akan masuk dalam klasifikasi gaya era masa lalu, tentu hal ini melalui kacamata masyarakat pengagum mode.

Kemunculan mode ini memang tidak datang sesederhana seperti apa yang kita banyangkan. Kemunculan ini tentu melalui beberapa fase dan kepentingan. Ada beberapa tahapan yang penulis jabarkan disini tentu dalam kontek Indonesia. Pertama: bahwa munculnya Kerudung/Hijab/Jilbab yang marak di Indonesia baru muncul pasca tumbangnya rezim Orde Baru. Pada waktu itu ditandai dengan munculnya "kerudungisasi" di kalangan masyarakat kampus. Orde Baru adalah dimana Kerudung/Hijab/Jilbab menjadi sebuah hal yang masih awam untuk dipakai. Hal ini memang sangat terkait dengan situasi politik dan budaya pada masa itu. Peperangan yang panjang pasca kemerdekaan, sampai kondisi pemerintah yang antipati terhadap gerakan ekstrimis kanan yang terwakilkan oleh gerakan DII dan Negara Islam Indonesia hingga terakhir tragedi Tanjung Priok berdampak pada pengamalan agama Islam. Selain itu juga kebijakan pemerintah yang cukup represif terhadap pengawasan kegiatan pengamalan agama dan syiar Islam yang dilakukan sejumlah organisasi Islam juga berdampak pada sosialisasi atas Kerudung/Hijab/Jilbab ini, sehingga dampaknya sangat terlihat pada masa Orde Baru sedikit muslimah yang memakai Kerudung/Hijab/Jilbab.

Kedua: era tahun 90-an, pemerintah cukup mulai memperhatikan kehidupan beragama. Hal ini sebagai sebuah dampak dari kehidupan pribadi Soeharto yang sudah mulai berusia lanjut. Religiusitas Soeharto meningkat ditandai dengan berangkatnya haji dan umroh yang selalu dipertontonkan melalui media, hal ini dampaknya cukup bagus, kelonggaran beragama mulai ditunjukan dengan beberapa surat keputusan presiden yang dikeluarkan.

Ketiga: pasca reformasi ada sekolompok masyarakat yang menginginkan kehidupan Islami di setiap lini aktivitas, dan juga dibarengi dengan kebebasan berekspresi, hal ini semakin mempermudah segala aktivitas hidup sesuai dengan ideologi masing-masing. Keempat. kemudian fase yang terakhir inilah yang menyuburkan symbol-simbol agama dipakai dalam kehidupan, termasuk Kerudung/Hijab/Jilbab. Sebuah catatan yang penulis tekankan adalah pada awalnya masyarakat belum berfikiran akan memodifikasi gaya Kerudung/Hijab/Jilbab mereka. hal ini tentu saja dapat dipahami bahwasanya, masyarakat baru belajar memakai simbol baru yang sebenarnya sudah lama dikenal, dampaknya adalah normative, dan masih sesuai dengan ketentuan yang selaras dengan dalil.

Fase selanjutnya memang Kerudung/Hijab/Jilbab menjadi trend masyarakat muslimah indonesia. hal ini mendorong pula dimunculkanya aturan-atruran yang melegalkan Kerudung/Hijab/Jilbab, terutama di instansi-instansi islam yang sebagai lembaga pendukung kebudayaan ini. Dampaknya massive Kerudung/Hijab/Jilbab menjadi hal yang biasa atau lumrah pada perkembangan selanjutnya. Kelumrahan inilah sebenarnya akar dari sebuah upaya desakralisasi Kerudung/Hijab/Jilbab itu sendiri, ditambah penekanan pada esensi kewajiban berkerudung bagi seorang muslimah mulai ditinggalkan, dan hanya sebatas peraturan berkerudung yang diberlakukan, terutama untuk sekolah Islam. Tentu saja hal ini tidak mewadahi jikalau muncul sebuah apologistik, terhadap esensi berkerudung. ${ }^{10}$

\section{Jilbab dalam Islam}

Dalam Islam kata Jilbab, yang bentuk jamaknya Jalabib dalam Al-Qur'an di sebutkan dalam surah alahzab ayat 59 yang artinya "Hai Nabi, katakanlah kepada istri-istri mu, anak-anak perempuan mu dan istri-istri orang mukmin: hendaklah mereka mengulurkan Jilbabnya keseluruh tubuh mereka." Jilbab/Hijab yang hakiki adalah menutupi seluruh anggota tubuhnya selain wajah dan kedua telapak tangan. ${ }^{11}$ tidak keluar rumah dengan berdandan. Yakni, terdapat Hijab materi yang berupa penutupan tubuh, dan juga Hijab rohani dimana sosok wanita sebagai manusia ditengah-tengah masyarakat, tidak berusaha tampil dengan dandanan yang menarikperhatian. ${ }^{12}$

Pemakaian Jilbab disyariatkan bagi setiap mukminat yang sudah akil balig. Cara penetapan syariat tentang pemakaian jilbab ini bertahap, ketentuan-ketentuannya turun secara berangsur sehingga manusia tidak dikejutkan dengan perubahan ketentuan dalam masalah aurat. Jilbab pun seharusnya disesuaikan dengan kriteria Islami yang berupa Jilbab hati yang terpencar dari sifat, perbuatan serta perkataan. ${ }^{13}$

${ }^{10}$ http://thisisgender.com (diakses pada tanggal 10 desember 2014).

${ }^{11}$ Abdurrahman Nassantari, Resiko Buruk Busana Seksi (Jakarta: Pustaka Al-Kautsar, 2008), 169.

${ }^{12}$ Sayyid Muhammad Husain Fadhlullah, Dunia Wanita dalam Islam (Jakarta: IKAPI, 2000), 108-109.

${ }^{13}$ Ahmad Barjie B, Wanita, Keluarga dan Pendidikan Anak (Banjarmasin: Pustaka Banua, 2014), 344. 
a. Dalam surah al-'Araf ayat 26 dijelaskan bahwa Allah SWT telah menurunkan (menyediakan) pakaian bagi manusia untuk menutup aurat.

b. Dalam surah al-Nur ayat 30 Allah SWT member petunjuk bagi kaum mukminin menahan diri untuk tidak memandang wanita (yang bukan mahramnya) dan memelihara kemaluannya (naluri seks). Sebaliknya, pada surah al-Nur ayat 31 para wanita mukminat juga diperintahkan agar tidak memandang kepada laki-laki dan memelihara kemaluannya (seks). Bahkan dalam kelanjutan ayat 31 ini para wanita dianjurkan untuk tidak menampakkan perhiasannya, selain perhiasan yang biasa Nampak, kecuali kepada laki-laki mahramnya, yaitu suami, ayah, ayah suami, putra-putranya, putra-putra suami (anak tiri), saudara-saudaranya, putra dari saudara perempuan, wanita-wanita islam, budak-budak yang dimiliki, pelayan laki-laki yang sudah tidak mempunyai keinginan terhadap wanita, dan anak-anak yang belum mengerti tentang aurat wanita.

c. Pada surah al-Ahzab ayat 33 Allah SWT menganjurkan kepada istri-istri Nabi SAW agar tetap dirumah dan tida berhias seperti orang-orang jahiliyah (kafir sebelum datangnya islam) yang cenderung mempertontnkan perhiasan/tubuhnya. Larangan ini oleh Allah SWT dimaksudkan sebagai usaha menghilangkan dosa dari keluarga Rasulullah SAW.

d. Pada surah al-Ahzab ayat 59 dengan tegas Allah memerintahkan kepada Nabi SAW agar mengatakan kepada Istri-istrinya, anak-anak perempuannya, dan juga perempuan-perempuan mukminat agar mereka mengulurkan jilbabnya keseluruh tubuh mereka. Dalam ayat ini Allah SWT juga telah menjelaskan tujuan dari perintahnya tersbut, yaitu: Pertama, upaya mereka lebih mudah untuk dikenal sebagai wanitabaik-baik, merdeka, dan telah berkeluarga. Kedua, supaya mereka tidak digangu, disakiti, atau diperlakukan tidak senonoh oleh laki-laki, untuk membendung terjadinya perbuatan yang diharamkan. ${ }^{14}$

Fungsi Jilbab yang disyariatkan dalam islam ini adalah untuk menutupi aurat wanita yang diwajibkan untuk ditutup. Sampai seberapa ukuran tubuh yag harus ditutup dengan jilbab akan sangat tergantung pada pemahaman ulama terhadap nas-nas Al-Qur'an dan Sunnah yang bersifat Zanni (dapat ditafsirkan), dan pendapat para fuqaha dalam ijtihad mereka tentang batas aurat wanita sebagaimana digariskan dalam firman Allah SWT surah al-Nur ayat 31 yang artinya ".janganlah mereka menampakkan perbiasannya kecuali yang bisa Nampak dari padanya". Perbedaan pendapat ulama tentang aurat tersebut adalah sebagai berikut. Pertama, jumhur fuqaha, diantara madzhab-madzhab Maliki, Syafi'i, Ibnu Hazm, Syiah Zaidiah, yang masyhur dari Hanbali dan salah satu riwayat madzhab Hanafi dan Syiah Imamiah yang diriwayatkan dari tingkatan tabi'in seperti Ata dan Hasan Bashri, dan tingkatan shahabat seperti Ali bin Abi Thalib, Aisyah dan Ibnu Abbas berpendapat bahwa: "Hanya muka dan kedua telapak tangan saja yang bukan termasuk aurat bagi kaum wanita." Kedua, Sufyan Ats-Tsauri, mazin dan salah satu dalam kalangan madzhab Hanafi mengatakan bahwa muka, telapak tangan dan telapak kaki tidak termasuk aurat bagi kaum wanita. Ketiga, salah satu pendapat dalam kalangan madzhab Hanbali dan sebagian Syiah Zaidiah da Zahiri berpendapat bahwa hanya muka saja dari tubuh wanita yang tidak termasuk aurat. Keempat, salah satu riwayat dari Imam Ahmad bin Hanbal dan pendapat Abu Bakar bin Abdurrahman dari kalangan Tabi'in mengatakan bahwa sekluruhbtubuh wanuta tanpa pengecualian adalah Aurat. ${ }^{15}$

Jilbab, dalam arti pakaian panjang berbentuk baju kurung yang menutupi seluruh tubuh termasuk muka, kepala, dan dada, lebih dekat dengan pengertian Burdah, suatu suatu pakaian model Jubah atau toga yang terbuat dari bulu domba atau kain biasa dengan cirri-ciri longgar, besar, luas dan menutupi sebagian besar anggota badan. Pakaian semacam ini sebenarnya telah ada dikalangan bangsa Arab sebelum Islam, baik yang dipakai oleh wanita yang dalam bahasa Arab disebut Jilbaab maupun yang dipakai oleh pria yang disebut Burdah.

Maksud pemakaian Jilbab dan Burdah juga berbeda-beda. Dikalangan bangsa Arab sebelum Islam, wanita berjilbab dipandang sebagai wanita baik-baik, walaupun jilbab pada masa itu hanya menutupi kepala dan rambut yang masih terlihat. Wanita yang tanpa jilbab oleh Masyarakat Arab dianggap bermartabat rendah. Jilbab untuk pria biasanya disebut burdah atau jubah biasanya dipakai sebagai pakaian kebesaran atau sebagai pelindung badab dari suhu udara maupun debu padang pasir.

Bahan yang dipergunakan untuk membuat Jilbab biasanya disesuaikan dengan iklim daerah, status sosial, dan tingkat kemalmpuan sipemakai. Jibab biasanya dibuat dari bahan tenunan bulu domba (wol), kain katun dan sutera. Ada yang tebal menutupi badan dan ada pula yang tipis tembus pandang. Tetapi setelah

${ }^{14}$ Dewan Redaksi Ensiklopedia Islam, Ensiklopedia Islam jilid 2 (Jakarta: Ichtiar Baru Van Hoeve, 1997), 317.

${ }^{15}$ Dewan Redaksi Ensiklopedia Islam, Ensiklopedia Islam jilid 2, 317-318. 
kedatangan Islam, sesuai dengan syariat menutup aurat, jilbab untuk wanita dibuat dari bahan yang dapat menutupi aurat. ${ }^{16}$

\section{Fenomena Jilboobs}

1. Pengertian Jilboobs

Di era saat ini Fashion semakin beragam dan menarik. Apalagi dengan adanya tren fashion para perempuan muslim yang menggunakan jilbab. Sudah bisa dilihat di berbagai tempat umum, penggunaan hijab saat ini semakin bertambah dan bervariasi dengan tetap menggunakan pakaian muslim yang menutupi seluruh tubuh. Namun, tren fashion para perempuan muslim menjadi buruk karena munculnya Fenomena Jilboobs. Sebenarnya fenomena ini berkembang melaui social media seperti Facebook.

Secara etimologi, istilah jilboobs merupakan gabungan dua kata. Yakni, jilbab dan boobs (dada wanita/orang dungu). Istilah itu merupakan sindiran kepada para perempuan muslim yang mengenakan hijab, tetapi sangat ketat sehingga lekuk tubuhnya terlihat jelas, terutama bagian dada. Hal tersebut jelas tidak sesuai dengan konsep berpakaian Islam yang syar'i, yakni tertutup, tidak membentuk lekuk tubuh (longgar), dan tidak tembus pandang (transparan).

Ketika istilah "Jilboobs" mengemuka seiring kritikan yang bertubi untuk muslimah yang dinilai berjilbab tapi tak syar'i, ada muslimah yang masih harus mengumpulkan keberanian ketika ingin menggunakan jilbab. ${ }^{17}$

Ada beberapa kesalahan saat berhijab, yaitu:

a. Jilbab Pendek

Beberapa wanita yang ingin tampil modis kerap menggunakan jilbab pendek. Bila jilbab pendek dipadukan dengan busana ketat sehingga menonjolkan bagian dada, itu disebut Jilboobs. Namun bukan berarti semua hijabers yang mengenakan jilbab termasuk jilboobs. Karena, jilbab pendek bisa disiasati dengan berbagai cara, misalnya memakai tambahan syal sehingga tetap menutup dada. Jika syal tidak cocok untuk pergi kekantor atau acara formal lainnya bisa melengkapi dengan blazer atau sejenisnya.

b. Atasan yang ketat

Busana ketat seharusnya tidak dipakai lagi oleh wanita setelah berhijab. Atasan ketat hanya dipakai sebagai dalaman saja. Bila masih menggunakan ataasan ketat maka bisa bisa disebut jilboobs.

c. Memakai Legging

Sebagian wanita senang menggunakan legging dengan alasan nyaman. Namun penggunaan legging sebaiknya sudah tidak dipakai lagi oleh hijabers sebagai luaran. Bagi wanita berhijab, legging hanya sebagai dalaman saja. Jika wanita masih mengenakan legging kemudian dipadukan dengan atasan yang ketat, maka bisa dikatakan itu adalah jilboobs.

d. Memperlihatkan bentuk pinggul

Wanita yang dikategorikan sebagai jilboobs tidak hanya memakai atasan ketat tapi juga celana yang membentuk bagian pinggul. Jika celana yang dipakai membentuk pinggul, sebaiknya diganti yang lebih longgar.

e. Transparan tanpa dalaman

Beberapa hijabers masih kurang memperhatikan busana yang dipakai ketika bepergian. Sebagian dari mereka masih menggunakan tank top sebagai dalaman atasan transparan. Padahal tank top belum tentu menutupu tubuh ketika memakai busana transparan.

2. Awal Kemunculan Jilboobs

Jilboobs berawal dari sebuah akun Facebook bernama Jilboobs Community. Akun tersebut mulamulanya menuliskan "Indahnya saling berbagi, diolah dari berbagai sumber" sebagai deskripsi akun Jilboobs. Akun yang sudah memiliki tiga ribu lebih likes, dan sudah mengunggah foto sebanyak 26 foto yang diposting pada 29 Januari 2014.

Jilboobs, akronim dari Jilbab dan boobs (dada) ini menjadi istilah yang makin ramai diperbincangkan di media sosial pada awal Agustus 2014. Sebagian orang sudah mendengarnya sejak

${ }^{16}$ Dewan Redaksi Ensiklopedia Islam, Ensiklopedia Islam jilid 2, 318.

${ }^{17}$ http://www.malang-post.com (diakses pada tanggal 29 November 2014) 
setahun silam, yakni merujuk pada cara berpakaian wanita berkerudung yang masih menggunakan pakaian ketat membentuk tubuh, terutama di bagian atas atau dada.

Gaya berpakaian kembali kepada selera personal. Kalau bicara fashion, tren yang berkembang saat ini adalah setiap orang punya personal style yang menjadi karakter dan mengidentifikasikan dirinya. Hal ini juga berlaku untuk muslimah. Namun, terlepas dari berjilbab adalah salah satu cara perempuan menjalankan ajaran agama, ketika seorang perempuan memutuskan memakai jilbab, memakai busana tertutup, maka ia telah mengidentifikasikan dirinya sebagai muslimah yang punya tatacara tersendiri dalam berbusana. Artinya, gaya busana muslimah selain menunjukkan identitas dirinya, gaya personalnya, semestinya juga mengikuti tatacara berpakaian yang semestinya.

Kembali kepada Jilboobs, istilah yang merujuk cara berpakaian sebagian perempuan berkerudung, ini sebenarnya bukan isu baru. Fenomena ini juga pernah muncul setahun silam dengan istilah berbeda. ${ }^{18}$

\section{Fenomena Jilboobs dalam Analisis Semiotika Roland Barthes}

1. Pengertian Semiotika

Semiotika berasal dari studi klasik dan skolastik atas seni logika, retorika, dan poetika. ${ }^{19}$ Ferdinand de Saussure mengartikan semiotika sebagai "ilmu yang menelaah tentang tanda sebagai bagian dari kehidupan sosial". Ia juga merupakan sebuah model ilmu pengetahuan sosial yang disebut "tanda". Kemudian menurutnya, ada suatu hubungan antara penanda dan petanda yang bersifat diada-adakan, sebab tidak ada ketertarikan logis. ${ }^{21}$ Semiotika berasal dari bahasa Yunani, semeion yang berarti tanda. Tanda itu sendiri didefinisikan sebagai sesuatu yang dapat mewakili sesuatu yang lain atas dasar konvensi sosial. Semiotik juga meiliki jenis seperti semiotik medik (mengkaji hubungan antar tanda) dan semiotik umum (menjelaskan semua fungsi tanda berdasarkan system hubungan satu kode atau lebih). ${ }^{22}$ Istilah semiotika sering digunakan bersama dengan istilah semiologi. ${ }^{23}$

Barthes menegaskan semiologi mendalilkan dua istilah, yakni penanda dan petanda. Dalam konteks ini kita perlu berhati-hati sebab dalam bahasa keseharian, ada yang mengatakan bahwa penanda mengungkapkan petanda, dan sistem semiologi kita tidak hanya dihadapkan dengan dua istilah, melainkan tiga istilah yang berbeda. Tiga istilah itu adalah penanda (gambaran akuistik), petanda (konsep) dan tanda (hubungan antara konsep dan citra). Yang pertama dan kedua ada sebelum mereka bersatu dan membentuk objek ketiga, yakni tanda. ${ }^{24}$ Kedua istilah tersebut, semiologi dan semiotika tidak memiliki perbedaan yang substansif, tergantung dimana istilah itu popular. Ada kecenderungan istilah semiotika lebih popular dari pada semiologi, sehingga penganut mazhab Saussurean pun sering menggunakan istilah semiotika. Namun yang jelas keduanya merupakan ilmu yang mempelajari hubungan antara signs (tandatanda) berdasarkan kode-kode tertentu. Tanda-tanda tersebut akan tampak pada tindak komunikasi manusia lewat bahasa baik lisan maupun isyarat.

Semiotika pada dasarnya dapat dibedakan kedalam tiga cabang penyelidikan, yaitu sintaktika, semantika dan pragmatika. ${ }^{25}$ Sintaktika adalah cabang penyelidikan semiotika yang mengkaji hubungan formal diantara satu tanda dengan tanda-tanda yang lainnya. ${ }^{26}$ Sintaktis juga bisa dikatakan bagian atau cabang dari ilmu bahasa tentang seluk-beluk wacana. ${ }^{27}$

Semantik, sebagai istilah yang digunakan untuk bidang linguistik. ${ }^{28}$ adalah cabang penyelidikan semiotika yang mempelajari hubungan antara tanda-tanda dengan designate atau obyek-obyek yang

\footnotetext{
${ }^{18}$ http://blog.kompasiana.com (diakses pada tanggal 25 November 2014).

${ }^{19}$ Kurniawan, Semiologi Roland Barthes (Magelang,: Anggota IKAPI, 2001), 49.

${ }^{20}$ Yasraf Amir Piliang, Bayang-Bayang Tuhan : Agama dan Imajinasi (Jakarta: Mizan Publika, 2011).

${ }^{21}$ Yasraf Amir piliang, Hiper Realitas Kebudayaan (Yogyakarta: LKiS, 1999), 115.

22Mansoer Padeta, Semantik Leksikal (Jakarta: Rineka Cipta, 2001), 34.

${ }^{23}$ Akhmad Muzakki, Kontribusi Semiotika dalam Memahami Bahasa Agama (Malang: UIN Malang Press, 2007), 11.

${ }^{24}$ Roland Barthes, Mitologi (Yogyakarta: Kreasi Wacana, 2004), 186-187.

${ }^{25}$ Fatimah Djadjasudarma, Semantik I (Bandung: Eresco, 1993), 21.

${ }^{26}$ Akhmad Muzakki, Kontribusi Semiotika dalam Memahami Bahasa Agama, 11-12.

${ }^{27}$ Ramlan, Sintaktis (Yogyakarta: Karyono, 1995), 21.

${ }^{28}$ Abdul Chaer, Pengantar Semantik Bahasa Indonesia (Jakarta: Rineka Cipta, 1990), 2.
} 
diacunya. Yang dimaksud designate adalah makna tanda-tanda sebelum digunakan didalam tuturan tertentu. ${ }^{29}$ Bisa dikatakan bahwa semantik itu adalah ilmu tentang makna atau arti. ${ }^{30}$ Bisa juga dikatakan bahwa semantik yakni lambang atau sign. ${ }^{31}$

Pragmatika adalah cabang penyelidikan semiotika yang mempelajari hubungan diantara tanda-tanda dengan interpreter-interpreter atau para pemakai tanda-tanda. Pragmatik secara khusus berurusan dengan aspek-aspek komunikasi, khususnya fungsi-fungsi situasional yang melatari tuturan.

\section{Elemen Dasar Semiotika}

Pembahasan mengenai elemen dasar semiotika ini penulis batasi pada tiga persoalan, yaitu: komponen tanda, relasi tanda, dan tingkatan tanda.

a. Komponen Tanda

Dalam perkembangannya, semiotika menganut dikotomi bahasa yang dikembangkan Saussure, yaitu tanda memiliki hubungan antara penanda dan petanda. Penanda adalah aspek material, seperti suara, huruf, bentuk, gambar, dan gerak, sedangkan petanda adalah aspek mental atau konseptual yang ditunjuk oleh aspek material. Sehingga kedua aspek ini tidak bisa dipisahkan.

b. Relasi Tanda

Didalam konteks strukturalisme bahsa, tanda tidak dapat dilihat hanya secara individu, akan tetap dalam relasi dan kombinasinya dengan tada-tanda lainnya didalam sebuah system. Analisis tanda berdasarkan system atau kombinasi yang lbih besarini melibatkanapa yang disebut aturan pengkombinasian yang terdiri dari duamodel relasi, yaitu relasi sintagmatik dan relasi paradigmatik.

Relasi sintagmatik adalah sebuah relasi yang merujuk kepada hubungan antara satu kata dengan kata-kata lain. Sedangkan relasi paradigmatic adalah relasi yangs setiap tanda berada dalam kodenya sebagai bagian dari suatu paradigm. Dengan kata lain relasi paradigmatik adalah cara pemilihan dan pengkombinasian tanda-tanda berdasarkan aturan atau kode tertentu, sehingga dapat menghasilkan sebuah ekspresi bermakna.

c. Tingkatan Tanda

Roland Barthes mengembangkan dua tingkatan pertandaan yang memungkinkan untuk dihasilkannya makna yang juga bertingkat-tingkat, yaitu tingkat konotasi dan denotasi. Denotasi adaah tingkat tingkat pertandaan yang menjelaskan hubungan antara penanda dan petanda, atau antara tanda dan rujukannya pada realitas,yang menghasilkan makna pasti. Makna denotasi dalam hal ini, adalah makna pada apa yang tampak. Misalnya, foto midun, berarti wajah midun yang sesungguhnya.

Konotasi adalah tingkat pertandaan yang menjelaskan hubungan antara penanda dan petanda, yang didalamnya beroprasi makna yang tidak langsung dan tidak pasti. Misalnya, tanda bunga, ia mengonotasikan kasih sayang. Jadi, denotasi adalah makna paling nyata dari tanda, sedangkan konotasi adalah istilah yang menunjukkan signifikasi tahap kedua. ${ }^{32}$

3. Biografi Roland Barthes Serta Karya-karyanya

Roland Barthes lahir di Cherbourg pada tahun 1915 dan tatkala ia masih kanak-kanak ayahnya meninggal dunia dalam suatu pertempuran. ${ }^{33}$ Sejak itulah ia diasuh oleh ibu dan kakek neneknya. Sebelum menyelesaikan sekolah dasar dan menengahnya di Paris, Barthes menghabiskan masa kecilnya di Bayonne, Prancis barat daya. Antara tahun 1943 dan 1947 ia menderita penyakit TBC, dan masa istirahatnya dimanfaatkan untuk membacabanyak hal, dan menerbitkan Artikel pertamanya tentang Andre Gide, setelah mengajar di Rumania dan Mesir, tepat pertemuannya dengan A.J. Greimas ia mengajar di Ecole des Hautes Etudes en sciences Sociales. Barthes diangkat dalam keanggotaan College de France pada tahun 1977, sampai akhir hayatnya tahun 1980.

Roland Barthes dikenal sebagai salah seorang pemikir strukturalis yang aktif memperaktekkan model linguistic dan semiologi Sausurean. Ia juga intelektual dan kritikus sastra prancis yang ternama,

\footnotetext{
${ }^{29}$ Akhmad Muzakki, Kontribusi Semiotika dalam Memahami Bahasa Agama, 12.

${ }^{30}$ Parera J.D, Teori Semantic (Jakarta: Erlangga, 2004), 42.

${ }^{31}$ Aminuddin, Semantik (Malang: Sinar Baru Algensindo Bandung, 2003), 37.

${ }^{32} \mathrm{Ahmad}$ Muzakki, Kontribusi Semiotika dalam Memahami Bahasa Agama, 12-25.

${ }^{33}$ Edith Kurzweil, Jaring Kuasa Strukturalisme, (Bantul: kreasi wacana, 2010), 246.
} 
eksponen penerapan strukturalisme dan semiotika pada study sastra. Bertens menyebutnyasebagai tokoh yang memainkan peranan sentral dalam strukturalisme tahun 1960-an dan 70-an. Ia berpendapat bahasa adalah sebuah system tanda yang mencerminkan asumsi-asumsi dari suatu masyarakat tertentu dalam waktu tertentu. Ia mengajukan pandangan ini dalam Writing Degree Zero dan Critical Essays. Setelah mengajar bahasa dan satra Prancis di Bukarest (Rumania) dan Kairo, tempat pertemuannya dengan Algirdas Julien Greimas, Ia mengajar di Ecole des Hautes Etudes en sciences Sociales. Setelah kembali bekerja ke Prancis, ia bekerja untuk Centre National de Recherche Scientifique. Melalui lembaga penelitian ini, ia banyak mengabdikan dirinya dalam berbagai penelitian dibidang sosiologi dan leksikologi. Disini ia banyak menulis tentang sastra. Dari tahun 1960, ia menjadi asisten dan kemudian menjadi directeur d'Etudes dari seksi keenam ecole pratique des hauntes etudes, sambil mengajar sosiologi tanda, symbol dan respresentasi kolektif serta kritik semiotika. Pada 1976, Barthes diangkat sebagai professor untuk semiologi literer di college de France. Tahun 1980 Ia meninggal pada usia 64 tahun akibat ditabrak mobil di paris sebulan sebelumnya.

Barthes telah banyak telah banyak menulis buku, yang beberapa diantranya telah menjadi bahan rujukan penting untuk study semiotika diindonesia. Karya-karya pokok barthes, antara lain: Le Degree Zero de Zecriture atau nol derajat di bidang menulis (1953), Mythologies (1957), Critical Essays (1964), Elements of Semiology (1964), The Fashion System (1967), S/Z (1970), A lovers discourse : Fragments (1977), Camera Lucida: Reflections on Photography (1980), dan lain-lain. ${ }^{34}$

\section{Analisis Semiotika Roland Barthes}

Dalam buku The Fashion System, Barthes membicarakan panjang lebar mengenai dunia mode. Buku ini merupakan suatu percobaan untuk menetapkan metode analisis truktural atas mode pakaian wanita. Sebagaimana bukunya yang terdahulu, dalam buku ini Barthes juga membicarakan operasi struktur penanda (signifier) mode, struktur petanda (signified)-nya, dan struktur sign atau signifikansinya. Memang kajian mode atau fashion Barthes tidak terlepas dari bidang semiotika yang selama ini dikembangkannya.

Tata busana tidak lagi menjadi sekedar pakaian tetapi juga telah menjadi mode, menjadi peragaan busana, menjadi sebuah tontonan yang memiliki prestisenya tersendiri, menjadi simbol status kehidupan. Hal ini tidak hanya terjadi di dunia Barat saja, tetapi juga tengah melanda Indonesia. Barthes tidak salah membidik salah satu aspek ini, yakni mode, sebagai salah satu kajiannya, mengingat Paris merupakan kiblat mode dunia. Begitulah, salah satu topik pembicaraan Barthes tentang aspek kebudayaan massa yakni tentang dunia mode. Dunia yang kini penuh dengan kemewahan para model yang memperagakannya di sejumlah catwalk pusat-pusat peragaan busana di berbagai kota metropolis. Status seseorang dalam masyarakat seringkali dicitrakan melalui merk dan rancangan siapa pakaian yang dikenakannya. Padahal kalau ditelusuri, dunia mode adalah salah satu pelegitimasi ideologi gender yang selama ini sering dikonter oleh para Feminis.

Dari penjelasan diatas mengenai mode atau Fashion berjilbab bisa kita analisis dengan metodenya Roland Barthes, bahwa Fenomena Jilboobs merupakan budaya Fashion yang sangat mempengaruhi cara berpakaian remaja muslimah dizaman sekarang, dengan alasan tak mau ketinggalan mode atau tidak Fashionable. Fungsi jilbab sendiri tak lagi sebagai penutup aurat tetapi malah menjadi mode yang menyalahi aturan-aturan agama seperti Jilboobs yang memperlihatkan bentuk dada dengan pakaian ketat.

Model berjilbab seseorang tak seharusnya menyesuaikan dengan fungsinya sebagai tanda, yang membedakan antara jilbab yang syar'i dengan mode-mode berjilbab lainnya untuk kantoran, olah raga, liburan, upacara-upacara tertentu, bahkan untuk musim-musim tertentu seperti jilbab musim dingin, musim semi, musim panas ataupun musim gugur. Manusia pengguna jilbab yang mengikuti trend akan mengejar apa yang tengah menjadi simbol status kelas menengah atas. Yang tidak mengikuti arus dunia mode akan dikatakan manusia yang tidak Fashionable alias ketinggalan mode. Seperti itulah yang melanda remaja muslimah sekarang, yang mengenyampingkan ajaran agama, dan terpengaruh oleh tren Fashion yang terus berkembang.

\section{Penutup}

Jilbab dalam bahasa Inggris "Veil" bisa dipakai untuk merujuk pada penutup tradisional kepala, wajah (mata, hidung atau mulut), atau tubuh wanita di Timur tengah dan Asia selatan. Sebagai kata benda, Veil 
berasal dari kata latin Vela, bentuk jamak dari Velum. Makna leksikal yang dikandung kata ini adalah "penutup", dalam arti "menutupi" atau "menyembunyikan atau menyamarkan".

Jilboobs merupakan gabungan dua kata. Yakni, Jilbab dan Boobs (dada wanita). Istilah itu merupakan sindiran kepada para perempuan muslim yang mengenakan Hijab, tetapi sangat ketat sehingga lekuk tubuhnya terlihat jelas, terutama bagian dada. Hal tersebut jelas tidak sesuai dengan konsep berpakaian Islam yang syar'i, yakni tertutup, tidak membentuk lekuk tubuh (longgar), dan tidak tembus pandang (transparan).

Semiotika sering digunakan bersama dengan istilah Semiologi. Barthes menegaskan Semiologi mendalilkan dua istilah, yakni penanda dan petanda. Dalam konteks ini kita perlu berhati-hati sebab dalam bahasa keseharian, ada yang mengatakan bahwa penanda mengungkapkan petanda, dan sistem Semiologi kita tidak hanya dihadapkan dengan dua istilah, tetapi tiga istilah yang berbeda, yaitu penanda (gambaran akuistik), petanda (konsep) dan tanda (hubungan antara konsep dan citra).

Mengenai mode atau fashion berjilbab bisa kita analisis dengan metodenya Roland Barthes, bahwa fenomena jilboobs merupakan budaya fashion yang sangat mempengaruhi cara berpakaian remaja muslimah dizaman sekarang, dengan alasan tak mau ketinggalan mode atau tidak fashionable. Fungsi jilbab sendiri tak lagi sebagai penutup aurat tetapi malah menjadi mode yang menyalahi aturan-aturan agama seperti jilboobs yang memperlihatkan bentuk dada dengan pakaian ketat.

Model berjilbab seseorang tak seharusnya menyesuaikan dengan fungsinya sebagai tanda, yang membedakan antara jilbab yang syar'i dengan mode-mode berjilbab lainnya untuk kantoran, olah raga, liburan, upacara-upacara tertentu, bahkan untuk musim-musim tertentu seperti jilbab musim dingin, musim semi, musim panas ataupun musim gugur. Manusia pengguna jilbab yang mengikuti trend akan mengejar apa yang tengah menjadi simbol status kelas menengah atas.

\section{DAFTAR PUSTAKA}

Dewan Redaksi Ensiklopedia Islam, 1997, Ensiklopedia Islam jilid 2, Ichtiar Baru Van Hoeve, Jakarta.

Kurniawan, 2001, Semiologi Roland Barthes, Anggota Ikapi, Magelang.

Muzakki, Akhmad, 2007, Kontribusi Semiotika dalam Memahami Bahasa Agama, UIN Malang Press, Malang.

Aminuddin, 2003, Semantik, Sinar Baru Algensindo Bandung, Malang.

J.D, Parera, 2004, Teori Semantik, Erlangga, Jakarta.

Kurzweil, Edith, 2010, Jaring Kuasa Strukturalisme, Kreasi Wacana, Bantul.

Kaelan, 2009, Filsafat Bahasa Semiotika dan Hermeneutika, Paradigma, Yogyakarta.

Ismail, Fuad farid \& Mutawalli, abd. Hamid, 2012, Cara Mudah Belajar Filsafat Barat dan Islam, , IRCISoD, Jogjakarta.

Shihab, M. Quraish, 2012, M. Quraish Shihab Menjawab, Lentera Hati, Tangerang.

El Guindi, Fadwa , 2005, JILBAB Antara Kesalahan, Kesopanan dan Perlawanan, Serambi Ilmu Semesta, Jakarta.

Ahmed, Akbar S, 1993, Posmodernisme (Budaya dan Harapan bagi Islam), Mizan, Bandung.

Fadhlullah, Sayyid Muhammad Husain, 2000, Dunia Wanita dalam Islam, Ikapi, Jakarta.

Al-Jamal, Ibrahim Muhammad, 2000, Tantangan Wanita Muslimah, Pustaka Azzam, Jakarta.

Nassantari, Abdurrahman, 2008, Resiko Buruk Busana Seksi, Pustaka Al-Kautsar, Jakarta.

Fadhlullah, Sayyid Muhammad Husain, 2000, Dunia Wanita dalam Islam, IKAPI, Jakarta.

Barjie B, Ahmad, 2014, Wanita, Keluarga dan Pendidikan Anak,: Pustaka Banua, Banjarmasin.

Piliang, Yasraf Amir, 1999, Hiper Realitas Kebudayaan, LKiS, Yogyakarta.

Padeta, Mansoer, Semantik Leksikal, 2001, Rineka Cipta, Jakarta.

Djadjasudarma, Fatimah, 1993 Semantik I, Eresco, Bandung. 
Piliang, Yasraf Amir, 2011 Bayang-Bayang Tuhan : Agama dan Imajinasi, Mizan Publika, Jakarta.

Barthes, Roland, 2004, Mitologi, Kreasi Wacana, Yogyakarta

Ramlan, 1995, Sintaktis, Karyono, Yogyakarta

Chaer, Abdul, 1990, Pengantar Semantik Bahasa Indonesia, Rineka Cipta, Jakarta.

\section{Sumber Lain}

http://www.malang-post.com (diakses pada tanggal 29 November 2014)

http://blog.kompasiana.com (diakses pada tanggal 25 November 2014)

http://thisisgender.com (diekses pada tanggal 10 desember 2014) 